\title{
PEMBERDAYAAN WANITA TANI MELALUI PENENTUAN HARGA POKOK PRODUKSI, PENGEMASAN DAN PEMASARAN GULA AREN DI KECAMATAN BATU BRAK LAMPUNG BARAT
}

\author{
Dewi Sukmasari ${ }^{1 *}$, Yenni Agustina ${ }^{1}$, Tiara Nirmala ${ }^{2}$, Kiagus Andi ${ }^{1}$ \\ ${ }^{1}$ Jurusan Akuntansi Universitas Lampung \\ ${ }^{2}$ Jurusan Ilmu Ekonomi Pembangunan Universitas Lampung \\ Jl. Soemantri Brojonegoro no.1 35142 Bandar Lampung \\ Penulis Korespodensi : dewsukma@gmail.com
}

\begin{abstract}
Abstrak
Kecamatan Batu Brak merupakan salah satu kecamatan penghasil gula aren di lampung barat. Produksi gula aren yang terus meningkat membuktikan bahwa gula aren lampung barat semakin diminati oleh khalayak ramai. Namun sayangnya sistem perhitungan harga pokok produksi yang masih tradisional, serta sistem pengemasan yang masih tradisional dan sistem pemasaran yang masih sederhana menjadikan gula ini belum menjangkau pemasaran hingga ke mancanegara. Padahal kabupaten Lampung Barat memiliki potensi yang sangat bagus untuk menjadi produsen gula aren yang besar. Berdasarkan hal tersebut maka, tim berinisiatif untuk membantu wanita tani sebagai salah satu mesin penggerak untuk menghasilkan gula aren melalui sosialisasi, pelatihan, pendampingan, dan monev penentuan harga pokok produksi dalam hal penentuan harga jual sehingga memiliki harga jual yang mampu bersaing, sistem pengemasan yang menarik dan sistem pemasaran yang efektif. Metode yang digunakan yaitu dengan metode pendampingan serta pelatihan. Program kegiatan ini pun mendapatkan resepon yang positif dari peserta.
\end{abstract}

Kata kunci: Harga Pokok Perhitungan, Pemasaran,dan pengemasan, gula aren

\section{Pendahuluan}

Gula aren merupakan salah satu hasil bumi di Lampung Barat khususnya di kecamatan Batu Brak yang semakin di minati oleh masyarakat. Produksi gula aren yang terus meningkat setiap tahunnya dengan rata-rata pertahun menghasilkan 170 ton menjadikan bukti bahwa gula aren kini telah mampu menembus pangsa pasar (Antara news diakses 5 Juli 2019). Hal tentu saja akan mempengaruhi tingkat pendapatan masyarakat petani tanaman aren di kecamatan Batu Brak selain hasil alam lainnya.

Harga jual yang kompetitif tentu saja akan mempengaruhi besaran laba yang akan diterima oleh wanta tani tersebut. Terkait dengan hal tersebut maka, salah satu komponen yang menentukan harga jual yaitu harga pokok produksi yang tepat. Penentuan harga pokok produksi yang tepat dapat membantu mengurangi ketidakpastian dalam penentuan harga jual (Slat, 2013 ; Rotika, 2013 ; Pradana, David, dan Treesje, 2014 ; Silvia, 2013). Harga pokok produksi yaitu kumpulan biaya produksi yang terdiri dari bahan baku langsung, biaya tenaga kerja langsung, dan biaya overhead pabrik yang total kesemuanya ditambah dengan produk dalam proses awal dan dikurangi dengan produk dalam proses akhir (Bustami \& Nurlela, 2010 ; Mulyadi, 2012). Pada situasi lapangan yang terjadi wanita tani disana masih menggunakan penentuan perhitungan harga pokok produksi yang masih bersifat sederhana dan masih belum memasukkan semua komponen BOP didalam penentuan harga pokok produksi, semisalnya penyusutan.

Faktor lain yang mempengaruhi penjualan selain HPP yaitu pemasaran. Selama ini wanita tani di daerah tersebut menggunakan sistem penjualan yang masih tradisional. Meski pangsa pasar telah mencapai luar propinsi disekitar sumatra namun strategi pemsaran yang lebih baik akan mampu untuk memperluas pangsa pasar wanita tani tersebut. Salah satu teknik pemsaran yang efektif yaitu pemsaran online. Pemasaran melalui internet merupakan wadah yang komersil untuk mempertemukan penjual dan pembeli diberbagai belahan dunia(Azadafar \& Bastam, 2011). Sehingga, dibutuhkan strategi pemsaran online yang baik karena hal ini dapat memberikan 
pengaruh yang positif dan signifikan terhadap minat beli konsumen (Jati \& Yuliansyah, 2017). Maka dengan demikian tidak menutup kemungkinan bagi wanita tani untuk mengembangkan usaha hingga ke daerah lain yang belum pernah dijangkau.

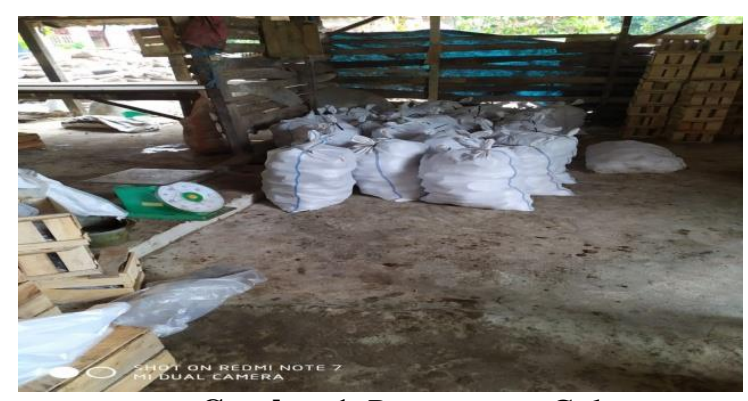

Gambar 1. Pengemasan Gula

\section{Metode Pelaksanaan}

Terkait dengan masalah utama yang dihadapi yaitu kurangnya pengemasan yang baik dan pemasaran yang masih sederahana, serta perhitungan harga pokok produksi yang masih bias, maka solusi yang akan diberikan yaitu berupa pendampingan dan pelatihan kepada wanita tani penghasil gula aren didaerah tersebut. Pendampingan dan pelatihan dilakukan selama kurang lebih 3 kali dengan rincian 2 hari pendampingan dan satu hari pelatihan. Pelaksaan kegiatan dilangsungkn pada tanggal 12-14 Agustus 2019.

\section{Hasil Pendampingan}

Gula aren merupakan salah satu hasil pertanian yang terdapat di Kabupaten Lampung Barat selain kopi dan lada yang mampu menjadi penghasilan tambahan bagi wanita tani di kabupaten tersebut. Proses pembuatan gula aren dilakukan dengan cara dan fasilitas yang masih tradisional.

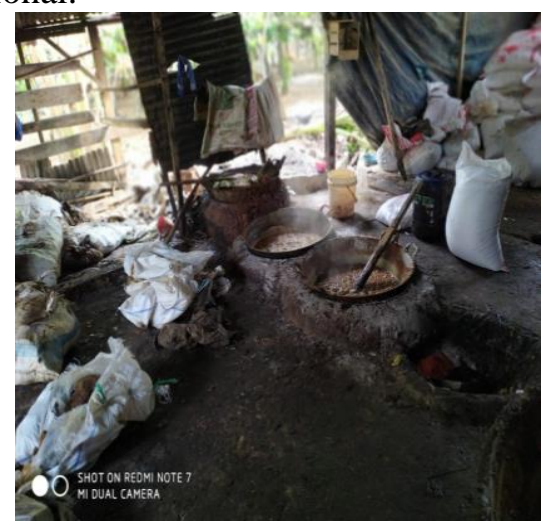

Gambar 2. Pengolahan Gula

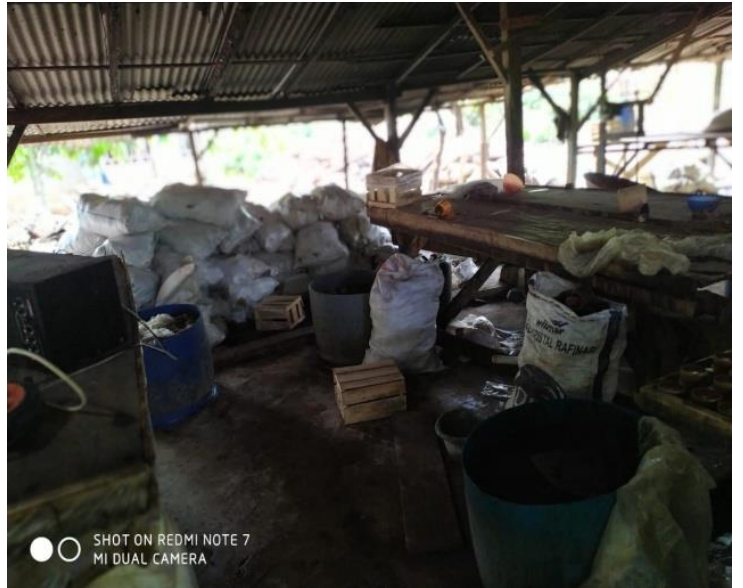

Gambar 2. Pengolahan Gula

Berdasarkan hasil pengamatan kami, wanita tani yang menjadi responden dalam kegiatan pengabdian ini masih menggunakan metoda perhitungan harga pokok produksi yang masih secara tradisional. Mereka mengabaikan akan adanya komponen lain pada biaya overhead pabrik. Sehingga, pada hari kedua kami mengadakan pelatihan mengenai perhitungan HPP (harga pokok produksi), pemasaran serta pengemasan yang sederhana namun menarik untuk menunjang pemasaran yang dilaksanakan pada tanggal 13 Agustus 2019 dirumah salah satu warga. Metode pemasaran yang kami ajarkan kepada wanita tani tersebut yaitu menggunakan media internet. Sebelum pelatihan dimulai responden diberikan ujian pre test yang kami bacakan atau pandukan, hal ini bertujuan untuk memudahkan dalam pengisian menimbang bahwa masih ada responden yang tidak memiliki keahlian membaca dan menulis.

Tabel 1. Pre test

\begin{tabular}{|l|l|l|l|l|}
\hline No & $\begin{array}{l}\text { Indikator/Tujuan } \\
\text { Instruksional } \\
\text { Khusus (TIK) }\end{array}$ & $\begin{array}{c}\text { Butir } \\
\text { Soal }\end{array}$ & $\begin{array}{c}\text { Jumlah } \\
\text { Soal }\end{array}$ & \% \\
\hline 1 & $\begin{array}{l}\text { Pengetahuan } \\
\text { Tentang Bahan } \\
\text { Baku }\end{array}$ & 1 & 1 & 10 \\
\hline 2 & $\begin{array}{l}\text { Pengetahuan } \\
\text { Tentang Tenaga } \\
\text { kerja langsung dan } \\
\text { kartu jam tenaga } \\
\text { kerja langsung }\end{array}$ & 2 & 2 & 10 \\
\hline 3 & $\begin{array}{l}\text { Pengetahuan } \\
\text { tentang BOP }\end{array}$ & 3 & 1 & 10 \\
\hline 4 & $\begin{array}{l}\text { Pengetahuan } \\
\text { tentang komponen }\end{array}$ & 3 & 3 & 10 \\
\hline
\end{tabular}




\begin{tabular}{|l|l|l|l|l|}
\hline & BOP & & & \\
\hline 5 & $\begin{array}{l}\text { Pengetahuan } \\
\text { tentang penentuan } \\
\text { sistem pencatatan } \\
\text { persediaan }\end{array}$ & 4 & 2 & 10 \\
\hline 6 & $\begin{array}{l}\text { Pengetahuan } \\
\text { tentang jurnal }\end{array}$ & 4 & 3 & 10 \\
\hline 7 & $\begin{array}{l}\text { Pengetahuan } \\
\text { tentang penyusunan } \\
\text { HPP }\end{array}$ & 4 & 1 & 10 \\
\hline 8 & $\begin{array}{l}\text { Pengetahuan } \\
\text { tentang pemasaran } \\
\text { menggunakan } \\
\text { media internet }\end{array}$ & 5 & 2 & 10 \\
\hline 9 & $\begin{array}{l}\text { Pengetahuan } \\
\text { tentang teknik } \\
\text { pemotretan yang } \\
\text { baik untuk } \\
\text { pemasaran }\end{array}$ & 5 & 3 & 10 \\
\hline 10 & $\begin{array}{l}\text { Pengetahuan } \\
\text { tentang } \\
\text { pengemasan yang } \\
\text { menarik }\end{array}$ & 5 & 1 & 10 \\
\hline
\end{tabular}

\begin{tabular}{|c|c|c|c|}
\hline & $\begin{array}{l}\text { Tenaga kerja } \\
\text { langsung dan } \\
\text { kartu jam } \\
\text { tenaga kerja } \\
\text { langsung }\end{array}$ & & \\
\hline 3 & $\begin{array}{l}\text { Pengetahuan } \\
\text { tentang BOP }\end{array}$ & 50 & 90 \\
\hline 4 & $\begin{array}{l}\text { Pengetahuan } \\
\text { tentang } \\
\text { komponen } \\
\text { BOP }\end{array}$ & 50 & 90 \\
\hline 5 & $\begin{array}{l}\text { Pengetahuan } \\
\text { tentang } \\
\text { penentuan } \\
\text { sistem } \\
\text { pencatatan } \\
\text { persediaan }\end{array}$ & 60 & 80 \\
\hline 6 & $\begin{array}{l}\text { Pengetahuan } \\
\text { tentang } \\
\text { jurnal }\end{array}$ & 40 & 70 \\
\hline 7 & $\begin{array}{l}\text { Pengetahuan } \\
\text { tentang } \\
\text { penyusunan } \\
\text { HPP }\end{array}$ & 50 & 90 \\
\hline 8 & $\begin{array}{l}\text { Pengetahuan } \\
\text { tentang } \\
\text { pemasaran } \\
\text { menggunaka } \\
\text { n media } \\
\text { internet }\end{array}$ & 50 & 70 \\
\hline 9 & $\begin{array}{l}\text { Pengetahuan } \\
\text { tentang } \\
\text { teknik } \\
\text { pemotretan } \\
\text { yang baik } \\
\text { untuk } \\
\text { pemasaran }\end{array}$ & 40 & 60 \\
\hline \multirow[t]{2}{*}{10} & $\begin{array}{l}\text { Pengetahuan } \\
\text { tentang } \\
\text { pengemasan } \\
\text { yang } \\
\text { menarik }\end{array}$ & 50 & 60 \\
\hline & Rata-rata & $57 \%$ & $79 \%$ \\
\hline
\end{tabular}

Tahap selanjutnya yang kami lakukan yaitu memberika pelatihan dengan menggunakan teknik ceramah dan diskusi. Sebagai tahap awal, tim memberikan materi yang kemudian diikuti dengan latihan soal yang diambil dari berbagai buku referensi. Soal tersebut berisikan dua soal yang pertama berupa pengelompokan biaya berdasarkan jenis biaya, yang kedua yaitu perhitungan HPP. Pada sesi kedua dilakukan pemberian materi mengenai pemasaran dan pengemasan yang baik dan menarik untuk menunjang pemsaran melalui internet seperti instagram maupun media penjualan online lainnya. Pada tahap terakhir dari pelatihan ini kemudian dilakukan uji post test yang bertujuan untuk mengukur tingkat pemahaman responden atas pelatihan yang telah dberikan. Berikut adalah tabel hasil uji post test dan pre test.

Tabel 2. Perbandingan hasil antara post test dan pre test.

\begin{tabular}{|l|l|c|c|}
\hline No & TIK & $\begin{array}{l}\text { Pre test } \\
(\%)\end{array}$ & Post test (\%) \\
\hline 1 & $\begin{array}{l}\text { Pengetahuan } \\
\text { Tentang } \\
\text { Bahan Baku }\end{array}$ & 100 & 100 \\
\hline 2 & $\begin{array}{l}\text { Pengetahuan } \\
\text { Tentang }\end{array}$ & 80 & 80 \\
\hline
\end{tabular}




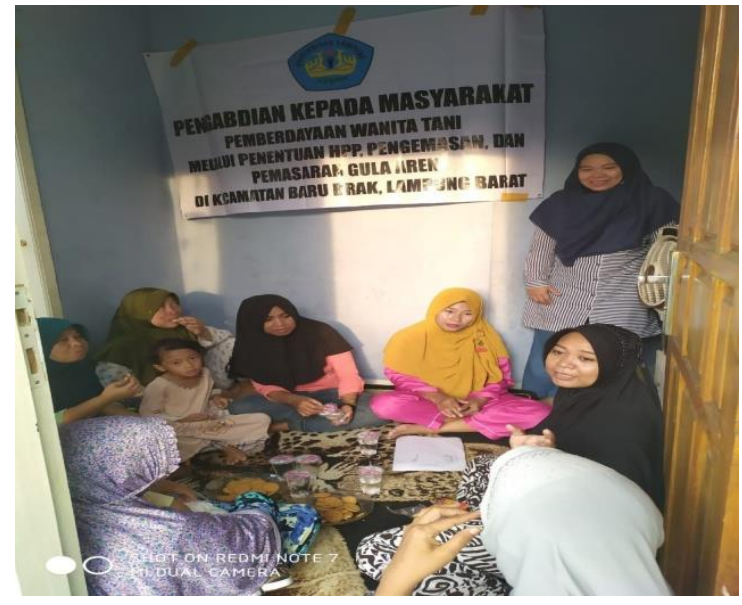

Gambar 4. Pelatihan

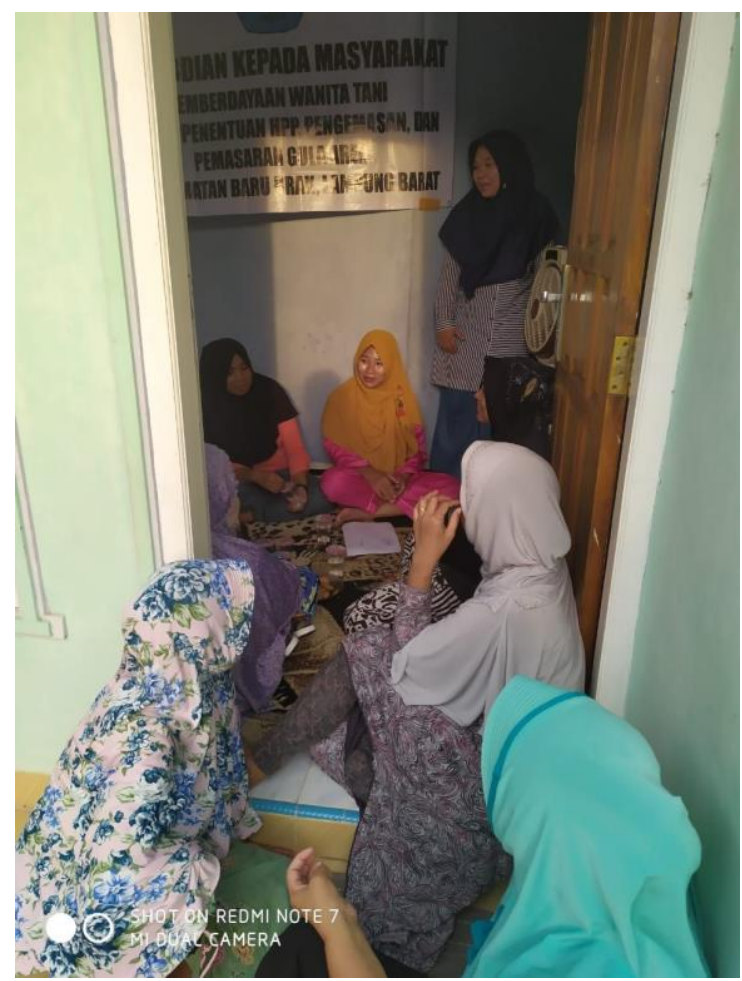

Gambar 5. Pelatihan

Hari ketiga kemudian tim mendatangi ke tempat pusat pengolah gula untuk terjun ke lapangan dan melakukan proses pendampingan. Proses pendampingan ini dilakukan selama satu hari setelah kegiatan pelatihan dan satu kali sebelum kegiatan pelatihan. Proses pendampingan ini langsung kami berikan kepada pemilik dari usaha pengolahan gula di kabupaten tersebut.

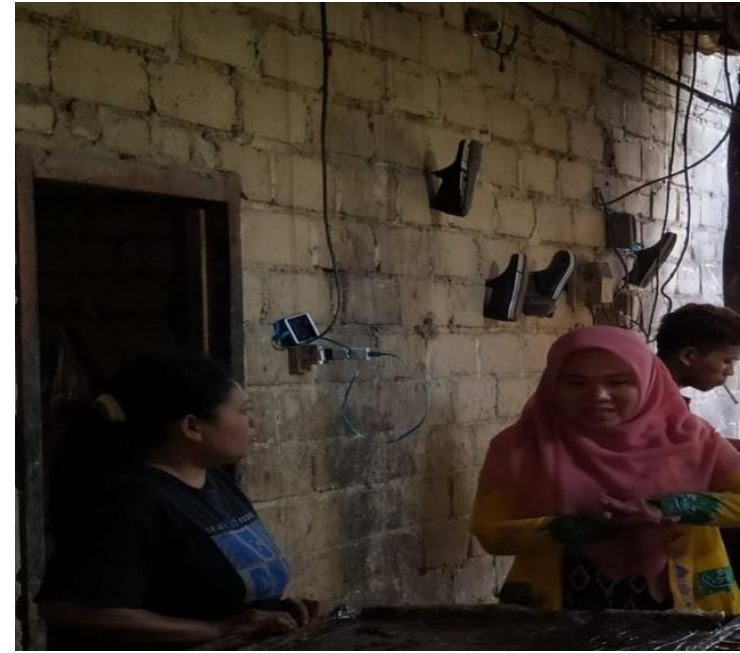

Gambar 6. Pendampingan

\section{Kesimpulan dan Saran}

A. Kesimpulan

Berdasarkan kegiatan yang telah dilaksanakan maka dapat ditarik kesimpulan yaitu sebagai berikut:

1. Wanita tani yang menjadi responden pada kegiatan ini sangat antusias dalam menerima kegiatan pelatihan dan pendampingan ini.

2. Dengan diberikan kegiatan pelatihan ini diharapkan mampu untuk meningkatkan volume penjualan serta kemudahan untuk menentukan harga produksi sehingga akan memudahkan wanita tani untuk mendapatkan bantuan dana dari Bank sebagai salah satu upaya untuk memperkuat modal usaha mereka.

\section{B. Saran}

Kegiatan pengabdian masyarakat semacam ini sebaiknya perlu dilakukan secara berkala dan meluas ke berbagai kelurahan dan kabupaten lain di propinsi Lampung.

\section{Ucapan Terimak Kasih}

Terima kasih dan penghargaan setinggi-tingginya kepada Ruslan selaku pemilik usaha dan warga kecamatan Batu Brak, Lampung Barat.

\section{Daftar Pustaka}

Azadavar, R, \& Bastam, S. 2011. Impact of Online/Internet Marketing in Enhancing Consumer Experience on Computer Industry. Research in Business 3.

Bustami \& Nurlela. 2010. Akuntansi Biaya. Yogyakarta: Graha Ilmu. 
Jati, W, \& Yuliansyah, H. 2017. Pengaruh Strategi Pemasaran Online (Online Marketing Strategy) Terhadap Minat Beli Konsumen (Studi Kasus pada Toko Online Shop Azzam Store). Jurnal Pemasaran Kompetitif, Vol.1 No.1.

Mulyadi. 2012. Akuntansi Biaya Ed ke -5. Yogyakarta: UPP STM YKPN.

Pradana Setiadi, David P.E. Saerang, Treesje Runtu 2014. Perhitungan HPP dalam penentuan harga jual CV Minahasa Mantab perkasa. Jurnal Berkala Ilmiah Efisiensi.: Volume 14 no. 2
Rotika, GS. 2013. Penerapan Metode ABC dalam Penentuan HPP pada PT. Tropica Cocoprima. Jurnal EMBA, Vol.1. No.3 Sept 2013, Hal.1019-1029.

Silvia Porawouw. 2013. Analisis perbandingan metode penentuan harga pokok produksi pada PT Bangun Wenang Baverage S Co. Jurnal EMBA. Vol.1 No.4, Hal. 1946-1952.

Slat, AH. 2013. Analisis Harga Pokok Produk dengan Metode Full Costing dan Penentuan Harga Jual, Jurnal EMBA, Vo.1.No.3. 